\title{
CARBON DIOXIDE AND CELL DIVISION
}
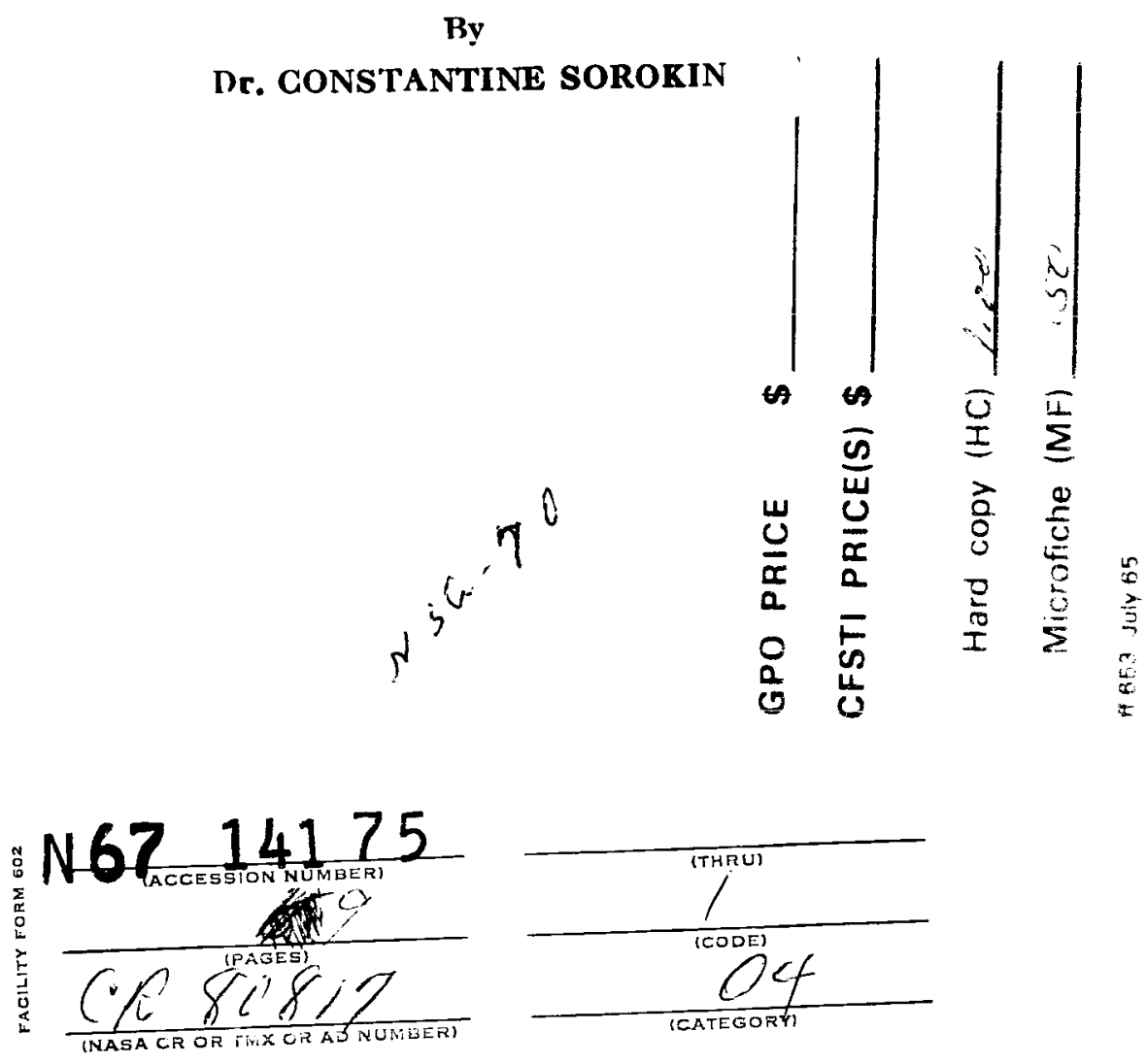

(Reprinted from Nature, Vol. 206, No. 4979, pp. 35-37, April 3, 1965) 


\section{CARBON DIOXIDE AND CELL DIVISION}

By definition, the discussion on the effects of carbon dioxide on cell division must be limited to the specific effects of carbon dioxide on this process. Growth and cell division are competitive, interdependent, and consecutive processes $^{1}$. Cell division occurs after a certain mass of protoplasm has been accumulated. Thus, cell division depends on growth. An unequivocal demonstration of the specific favourable effect of carbon dioxide on cell division would require proof that this seemingly beneficial effect is not actually due to the promoting effect of carbon dioxide on growth. If carbon dioxide is utilized by the cells in growth processes, this proof seems to be an arduous task.

In an attempt to prove a favourable effect of carbon dioxide on cell division, Mer and Causton (preceding article) resorted to references on the effect of carbon dioxide on growth ${ }^{2-6}$ which are largely irrelevant to the present discussion. In Geisler's work ${ }^{2}$, the favourable effect of carbon dioxide was demonstrated on root growth of pea seedlings. Though growth of multicellular organisms involves also cell division, Geisler ${ }^{2}$ did not attempt to discriminate between these two processes. He was interested in the morphogenic effects of carbon dioxide and the characteristics he studied were: dry weight of the main and lateral roots, length of the main root, and number of lateral roots.

Bach and Fellig 5 recorded a promoting effect of ethanol on the growth of Chlorella vulgaris, measured as increase in optical density. Observations on cell division were not attempted in those investigations and the term "cell division" has not been used in the title or text even once. Stimulation of growth was observed only under growthlimiting conditions, indicating that ethanol acted as a factor promoting heterotrophic growth.

A similar effect of ethanol on heterotrophic growth was reported by Street et al.6, who observed a promotion of growth in Chlorella vulgaris cells by ethanol only when the culture contained limiting concentrations of glucose or was maintained in inorganic medium under light-limiting conditions. The nutritional value of ethanol, as an agent promoting mesocotyl growth in oat seedlings ${ }^{3,4}$, has been paralleled in Mer's work ${ }^{7}$ by that of sucrose, glucose and mannitol.

To account for the similarity in stimulation of growth by carbon dioxide and ethanol, $\mathrm{Mer}^{8}$ offered two alternatives: either ethanol is formed from carbon dioxide and acts as an 
intermediato motabolite, or ethanol is used by cells in respiration and an increased carbon dioxide production acts as a promoting agent. It is easy to seo that the first alternativo clearly suggests the nutritivo valuo of both ethanol and carbon dioxide and the second alternative fails to exclude it.

In their reference to Loomis's work ${ }^{9}$ on the effect of carbon dioxide on sexuality in Hydra, Mer and Causton (preceding article) name carbon dioxide "as the fuctor actuating those divisions which result in gametogenesis in Hydra". Loomis ${ }^{10}$ observed that in water free from carbon dioxide, a Hydra bud grew into normal Hydra with six tontacles in two days. At $p \mathrm{CO}_{2}$ of 4 per cont of an atmosphere, the bud grow slowly and produced only three tontacles. Highor lovels of carbon dioxide inhibited growth of buds even more. With the inhibition of vegetativo growth, tho dovolopment of soxual organs was induced. Within a wook, testa and ovaries began to form on the tronted Hydra. 'Thus, inhibition of growth (and of cell divisious involvod in vogetativo growth) came first and, quantitativoly, was probably expressed much more than the later promotion of the growth of soxual organs. Cloarly, Loomis's obscrvations on the effect of carbou dioxide on soxuality in $H y d r a$ involve a complex problem of interrelations betwoen the development of different parts and organs in a multicellular organism. Morphogenic effects of carbon dioxide have been discussed by many investigators (soe refs. 9 and 11). The whole problem is, however, outside the discussion on tho specific effect of carbon dioxide on cell division.

Carbon dioxide in Mor and Causton's ${ }^{12}$ invostigations was administered as a protreatmont during tho first three days of the experimonts. Obsorvations on growth and coll numbors in mosocotyls and colooptiles woro continued until the seventh day. If growth was favour: ably affectod by carbon dioxide, thon tho coll proceediel quickly through its dovelopmental stages and entered coll division soonor than in the absence of the growth-promoting agont. However, this indirect finvourablo offect of carbon dioxide on cell division did not prove the specific mature of this offoct separato from that of carbon dioxide on growth.

It can be argued that, on the basis of observations on multicollular tissues, the favourablo offoct of carbon dioxido on coll division cammot bo altogothor discardod. Howovor, oxporimontation with systoms which pormit much moro rigorous control of coll microonvironmont and much moro prociso dolinontion of dovolopmontal stages inclicates that the possibility of such a favourable offect of carbon dioxido on cell division is improbuble.

In synchronized microbial colls, growth processes can bo, to somo oxtent, soparated in timo from coll division. 
By subjecting unicellular green algae to alternating periods of light and darkness, the great majority of cells present in the originally non-synchronized population can be brought into phase, that is, into more or less the same developmental stage. Then, by maintaining a suitable regimen, these cells can bo grown in such a way that the majority of cells proceed through devolopmental stages and enter cell division more or less uniformly and simultancously. In green algae, growth is then largely confined to light periods and cell division to dark periods.

A complete separation of cell division from growth is not possible in algae even during the dark period. As was shown by Meffert ${ }^{13}$, nitrogen assimilation and the increase in dry weight continue in synchronized Scenedesmus cells during the dark period. Under these conditions, uptake of nitrogen and growth are favoured by carbon dioxide, indicating that carbon dioxide is used by these cells in growth processes. However, despite the usage of carbon dioxide during growth in darkness and an expected indirect promoting effect of the increased growth rate on cell division, the direct inhibitory effect of carbon dioxide on division in Chlorella ${ }^{14-16}$ is so strong that the net effect of carbon dioxide results in suppression of cell division. Thus, the direct inhibitory effect of carbon dioxide on cell division in synchronized algal cells during dark periods must be quantitatively of a larger magnitude than can be detected experimentally, since the observable effect is actually a balance between the favourable effect of carbon dioxide on growth and its unfavourable effect on cell division.

Synchronized Chlorella cells, brought by means of autotrophic growth to the stage of readiness to cell division, divide in the course of time both in light and in darkness. In darkness they readily divide if suspended in a fluid buffered at a suitable $p H$. In unbuffered suspending fluids, as, for example, in distilled water, cell division proceeds in darkness to its completion in atmospheric and free from carbon dioxide air, but not in air supplemented with one per cent or more of carbon dioxide ${ }^{14,16}$.

Studies on the detrimental effect of carbon dioxide on cell division in unbuffered suspending fluids have been substantiated by observations on the inhibitory effect of carbon dioxide on cell division in algal cells also in buffered media ${ }^{17,18}$. Earlier extensive work on cell division in marine eggs indicated that in these cells also, carbon dioxide had a clear-cut detrimental effect on cell division ${ }^{19,20}$.

The specific inhibitory effect of carbon dioxide on cell division was thus demonstrated on unicellular algae and marine oggs in the absence of, or despite, heterotrophic growth. The inhibitory effect was most pronounced in unbuffered suspending fluids ${ }^{14,15}$. In unbuffered media, an increase in carbon dioxide concentration coincides with the decline in $p \mathrm{H}$ of the suspending fluid. 
Several observations indicated that a low $p \mathrm{H}$ of tho suspending fluid may drastically suppress cell divi$\operatorname{sion}^{14-16,21-24}$. Tho mechanism of action of low $p H$ has been a subject of speculation. The capacity of a cell to maintain its inner $p \mathrm{H}$ in media with wide differences in their $p H$ has been well documented in the literature ${ }^{25-27}$, and other evidence ${ }^{28}$ brought by Mer and Causton (precoding article) to that effect adds nothing to the wellostablished fact. However, the effect of carbon dioxide present in the medium on lowering the intracellular $p H$ may be different from that of other acids. Cell membranes are highly permeable to carbon dioxide and it has been reported ${ }^{26}$ that externally supplied carbon dioxide may lower the internal $p \mathrm{H}$ of the cell.

The main point, howevor, is that $\mathrm{H}$-ions do not need to penetrato the coll wall to affect coll activity ${ }^{27}$. Sevoral procosses essential for coll activity occur within the cell wall or at the coll surface. Of particular importanco is the secrotory activity of cells which has been recently shown 'to bo ossential for cell division ${ }^{10,22,29}$. It has boen domonstrutol that low $p H$ interforos with the socretory activily of colls ${ }^{22,29}$. Thus, if tho $p \mathrm{H}$ of the surrounding modium changes due to the changes in the concentration of carbon dioxido, it is most reasonable to expoct that tho docronso in $p \mathrm{H}$ beyond a certain point will adversoly affect cell division.

It must also be omphasized that "carbon dioxido may affoct cell metabolism directly and/or through its effect on $p \mathrm{H}^{\prime \prime 26}$. Thus, the effect on $p \mathrm{H}$ is only one of several functions of carbon dioxide as a factor of biological importance. In certain circumstances, "the $p H$ effect is obscured by the dramatic action on cell division of the dissolved undissociated carbon dioxide"15. My work"15 actually demonstrated that thero is an effoct of carbon dioxide other than that oxerted through changes in $p \mathrm{H}$. Several investigators ${ }^{19,30}$ emphasized this role of carbon dioxide in cell division and other biological processes. Mer and Causton (preceding articlo) would seom to be trying to forco an open door in their attempt to prove that carbon dioxide per se may act as an agent affecting coll growth and, in goneral, cell motabolism.

Buffering a suspending fluid removes that portion of carbon dioxide action which is oxorted by the dissociated carbonic acid on the $p \mathrm{H}$ of the modium. Several buffers wet in a more or loss similar way, and bicarbonate buffors uro as offective as others. Mor and Causton (preceding article) are boing somowhat fanciful in attempting to deny a 'fuvourable' effect of bicurbonate, as such, on coll growth or cell division. I actually never expressed mysolf on the subject, and, to limit tho discussion, I am still trying to avoid the broad problem of the utilization and of the affect of bienrbonato ions on metabolic procossos. As has 
been stated, "an investigation of simultaneous effects of carbon dioxide and of bicarbonate indicated that bicarbonate counteracts the adverse effect of carbon dioxide on cell division ..."16. Therefore, carbon dioxide "as a source of bicarbonate can, within proper concentration range, favourably affect cell division"16. Thus, only the buffering properties of bicarbonate are involved. The biological importance of bicarbonate is bound with its formation in the external medium as the result of vital activities of cells. Both carbon dioxide and cations can be supplied by the cells in the process of respiration and cell secretion.

To account for the discrepancies in the views on the effect of carbon dioxide on cell division expressed by Mer and Causton (previous article and ref. 12) on one side and by myself ${ }^{14-16}$ on the other side, I have proposed two hypotheses. One of these hypotheses was offered in the previous communication ${ }^{16}$; the other is elaborated in this article. These two hypotheses are not necessarily exclusive of each other. In one hypothesis ${ }^{16}$ / the role of $p H$ and its changes, as affected by carbon dioxide, bicarbonate, and cell secretions, was brought forth as possibly responsible for the differences in the observations made in these two laboratories. Due to the choice of experimental material and technique, the control of $p \mathbf{H}$ and of its effect on cell division was not feasible in Mer's and Causton's experiments.

In another hypothesis, the effect of carbon dioxide on growth, and the dependence of cell division on the amassment of cell material and therefore on growth, was emphasized. This became particularly necessary because several investigators, and among them Mer and Causton (previous article), fail to dissociate these two processes and to consider only the specific effects of carbon dioxide on cell division. The effect of carbon dioxide on growth, and, through it, on cell division, is not a subject of this dis. cussion. The complexity of conditions for the development of individual cells in multicellular tissues is such that other hypotheses could also be proposed to account for the favourable effect of carbon dioxide observed by Mer and Causton ${ }^{12}$.

Mer and Causton ${ }^{12}$ explained differences in the effects of carbon dioxide on cell division in oat mesocotyls (positive effect) and in coleoptiles (no effect) by assuming that a high concentration of carbon dioxide is required for cell division in the meristem, and that carbon dioxide "will influence mitosis only in a compact meristem such as that found at the node of the mesocotyl"12.

I made no attempt to evaluate the last hypothesis, since no theoretical considerations or comparative observations were laid at its basis except for the reference to the possible difference in reaction to the same environmental 
fictor (carbon dioxide) on the part of difforont plants ${ }^{12}$ aud of different organs of the same plant (previous article).

The universally recognized fact of genetic and physiological individuality makes comparative invostigations a difficult task. However, biological investigations would turn into piling of unidentified and unrelated observations if investigators, in dofonding their views, tako refuge overy timo in the specificity of their experimental material and techniques. An attempt must be made to rolate the diversified observations and to understand them from broad theoretical principles.

Preparation of this paper was supported by funds from the National Aeronauties and Space Arministration.

\section{Department of Botany, Univorsity of Maryland.}

${ }^{1}$ Sorokin, C., Biochim. Biophus, Acta, 38, 197 (1900).

: Geisler, G., Plant Physiol., 38, 77 (1963).

ser, C. J., Nature, 182, 1812 (1958).

- Mer, C. L., J. Exp. Rot., 10, 220 (1959).

s Bach, M. K., and Fellig. J., Nuture, 182, 1359 (1958),

- Street, II. I., Griftiths, D. J., Thresher, C. L., and Owens, M.. Neture, 182. $1300(1958)$.

${ }^{7}$ Mer, C. L., Ann. Bot., 23, 177 (1959).

- Mer, C. J.., J. Exp. Cell Res., 10, 220 (1959).

- Isoomis, W. 1'., Science, 126, 735 (1957).

10 Loomis, W. F., Scientific American, 200, 145 (1959).

11 Jartnicki-Garcia, S., Eren, J., and Pramer, D., Nature, 204, 804 (1964).

12 Mer, C. I., and Causton, D. R., Nature, 199, 360 (1963).

${ }^{13}$ Meflert, M.-E., Arch. Mikrobiol., 37, 49 (1960).

14 Sorolin, C., Nature, 194, 496 (1962).

is Sorokin, C., Arch. Mikrobiol., 44, 219 (196:).

16 Sorokin. C., Nature, 203, 1252 (1964).

${ }^{1}$ Soceler, C. J., Ried, A., and Strotmann, H., Beitr. Biol. Pflanzen, 40, 1959 (1904).

18 Galloway, R., Gauch, II., and Soeder, C. J., Plant Physiol. (Supp.), 39, VIII (1984).

${ }^{10}$ Clowes, T. H. A., and Smith, H. A., J. Biol. (Chem., 55, 19 (1923).

${ }^{20}$ Smith, II. W., and Clowes, G. H. A., Amer. J. Phlssiol., 68, 183 (1924).

${ }^{*}$ Sorokin, C., Exp. Cell Res., 27, 583 (1962).

"2 Sorokitı, (., Exp. Cell Res., 33, 508 (1904).

${ }^{23}$ Smith, H. W., and Clowes, G. IL. A., Biol. Bull., 47, 323 (1924).

94 Smith, II. W., and Clowes, G. II. A., Riol. Bull., 47, 3333 (1924).

${ }^{25}$ simall, J., Protoplasmatologia, 2, 132C: 1 (1955).

28 (aldwell. B. C., Internat. Rev. Cutol., 5, 229 (1956).

${ }^{27}$ Gratanin, M., and Georgiev, M., Faculle des sciences naturell's de l'minersiti de skonje, $13,5(1002)$.

${ }^{2}$ Rietsema, J., Ph.D., thesis (Utrecht, 1950).

"Sorokin. C., Protoplasma (in the press).

${ }^{30}$ Toomis, W. F., J. Nal. Cancer Inst., 22, 207 (1959)). 